\title{
MOLECULAR ASPECTS OF INHALATIONAL ANAESTHETIC INTERACTION WITH EXCITABLE AND NON-EXCITABLE MEMBRANES
}

\author{
David V. Godin and Giuseppe Del Vicario
}

\begin{abstract}
The interaction of three volatile general anaesthetics (halothane, enflurane and methoxyflurane) with ery throcyte membranes at concentrations causing protection of intact erythrocytes against hypotonic lysis was investigated in the hope of deriving fundamental information regarding the membrane perturbational characteristics of these substances as compared with those of local anaesthetics studied previously. The volatile agents increased the susceptibility of membrane proteins and, to a somewhat lesser extent, of phospholipids to trinitrophenylation by picryl chloride or trinitrobenzenesulfonic acid but decreased the accessibility of membrane protein sulfhydryl groups to modification by $5,5^{\prime}$-dithio-bis-(2-nitrobenzoic acid). These observations stood in marked contrast to our previous findings with local anaesthetics, in that these substances, when compared to general anaesthetics at concentrations producing equivalent erythrocyte stabilization, caused a greater enhancement of trinitrophenylation, largely restricted to the phospholipid component and an increased exposure of membrane sulfhydryl groups. Further evidence for alterations in membrane proteins produced by concentrations of volatile anaesthetics relevant to surgical anaesthesia was obtained from the observation that all three agents produced significant decreases in the activation energy of membrane-bound $p$-nitrophenylphosphatases. Preliminary experiments with brain synaptic membranes suggested that the structural and functional consequences of membraneanaesthetic interaction in erythrocytes are relevant to the situation in excitable tissues. Our results indicate, therefore, that general and local anaesthetics cause distinctly different alterations in the properties of model membrane systems and this may reflect corresponding differences in the molecular mechanisms by which these groups of agents produce their anaesthetic actions.
\end{abstract}

Key Words: Anaesthetics, volatile; Membranes, anaesthetic interaction.

ALTHOUGH A WEALTH of information concerning the electrophysiological and membrane perturbing properties of various classes of anaesthetics has been accumulated using a wide variety of experimental approaches, the molecular mechanisms by which these substances alter the functioning of excitable tissues has remained obscure. However, a number of recent observations would seem to make earlier unitary theories of anaesthesia based solely on critical volume expansion of lipoidal regions of excitable membranes by a chemically indifferent substance ${ }^{1}$ no longer tenable. These include pressure reversal studies, which tend to support the view of anaesthesia as a complex multisite phenomenon $;^{2}$ the critical dependence of the anaesthetic properties of certain steroids on molecular structure and the antagonism of their action by non-

David V. Godin, Ph.D., Associate Professor, Giuseppe Del Vicario, M.D., Research Fellow, Departments of Pharmacology and Anaesthesia, Faculty of Medicine, The University of British Columbia, 2176 Health Sciences Mall, Vancouver, B.C., Canada V6T IW5. anaesthetic steroids; ${ }^{3}$ and finally the observation that (-)naloxone is able to antagonize the cardiovascular depressant actions of halothane. ${ }^{4}$ It has long been recognized that cellular membranes are likely the primary site governing the production of anaesthesia. There has been much discussion concerning the role of membrane lipids in general and lipid fluidization in particular ${ }^{1.5,6}$ and, more recently, of membrane proteins $^{1.7 .8}$ in the action of anaesthetics. Detailed information concerning the interaction of anaesthetics with the structural components of membranes should provide greater insight into the molecular basis of anaesthesia and might indicate the extent to which general and local anaesthetics share common perturbational actions at the membrane level. ${ }^{9}$ The fact that both groups of agents are capable of stabilizing erythrocytes against hypotonic lysis at concentrations paralleling their nerve blocking concentrations ${ }^{10}$ is consistent with this latter possibility and suggests the erythrocyte as a valuable model membrane system with which to explore anaestheticmembrane interaction. 
Earlier studies from our laboratory ${ }^{11-13}$ have analyzed the membrane perturbational properties of substances with local anaesthetic activity in terms of effects on the incorporation of groupspecific reagents into erythrocyte membrane structural components and on the activity of membrane-associated enzymes. These experiments have provided evidence for alterations in the configurational state both of membrane proteins and of membrane phospholipids in the presence of these cationic lipophilic substances. In the present study the foregoing approach has been extended to a structurally distinct class of agent, the neutral volatile inhalational anaesthetics halothane, enflurane and methoxyflurane, using both erythrocytes and synaptosomes as models of electrically inexcitable and excitable membranes respectively.

\section{Methods}

\section{Preparation of Membranes}

Erythrocyte membranes were prepared from outdated human blood (stored in citratephosphate-dextrose) by stepwise hypotonic lysis, ${ }^{14}$ diluted to a protein concentration of $3-4 \mathrm{mg} / \mathrm{ml}$, quick-frozen using a dry ice/acetone mixture and stored at $-20^{\circ} \mathrm{C}$. Synaptosomal membranes from guinea pig brain were isolated by the sedimentation-flotation procedure of Jones and Matus. ${ }^{15}$ The material harvested from the interface of the discontinuous sucrose density gradient was diluted to a level of $3-5 \mathrm{mg} \mathrm{mem}-$ brane protein per $\mathrm{ml}$, quick-frozen and stored at $-20^{\circ} \mathrm{C}$. Cytochrome $\mathrm{c}$ oxidase measurements ${ }^{16}$ indicated a relatively low degree of mitochondrial contamination in these preparations $(11 \pm 1$ per cent).

\section{Antihaemolysis Studies}

The procedure employed was virtually identical to that described in our earlier studies ${ }^{13}$ and involved an incubation with drug under isotonic conditions followed by challenge with a hypotonic solution containing the same concentration of anaesthetic as was present in the preincubation. Since preliminary experiments indicated that the antithaemolytic effects of anaesthetics were independent of ambient temperature (in the range $5^{\circ}-37^{\circ} \mathrm{C}$ ), all the antihaemolytic studies were done at room temperature $\left(21 \pm 2^{\circ} \mathrm{C}\right)$. Samples were centrifuged and the extent of haemolysis was estimated from the absorbance at $540 \mathrm{~nm}$. Each experiment was performed in triplicate on freshly obtained blood samples from at least two different donors. In all of our studies involving the volatile anaesthetics care was taken to avoid losses during the course of the experiment. All containers used were kept tightly stoppered with teflon-lined caps, stock anaesthetic solutions were freshly prepared for each experiment and solutions once opened were not reused. Using these precautions, losses of halothane (the most volatile of the three agents employed) were found to be less than 10 per cent, on the basis of gas chromatographic analyses kindly done for us by Dr. Y.C. Pang, Department of Pathology, University of British Columbia.

\section{Labelling of Membranes with Picryl Chloride (PCl) or Trinitrobenzene-Sulfonic Acid (TNBS)}

Erythrocyte or synaptosomal membranes $(1.5 \mathrm{ml})$ were labelled with $\mathrm{PCl}$ or TNBS by incubation for one hour at $37^{\circ} \mathrm{C}$ in $12 \mathrm{ml}$ Tris buffer $(20 \mathrm{mM}, \mathrm{pH} 8.0)$ with or without volatile anaesthetic agent and $1.0 \mathrm{ml}$ TNBS solution $(10 \mathrm{mM}, \mathrm{pH} 8.0)$ or $0.5 \mathrm{ml} \mathrm{PCl}$ solution $(10 \mathrm{mM}$, in 1:1 (v:v) 95 per cent ethanol:water). Reactions were performed in $14 \mathrm{ml}$ total capacity glass tubes with teflon-lined lids. The recovery, solubilization and resolution by Sephadex G-200 chromatography of the protein and phospholipid components of labelled membranes were performed as described in our earlier studies. ${ }^{13}$ Alterations in membrane trinitrophenylation in the presence of volatile anaesthetics were evaluated from changes in the area (sum of absorbances at $335 \mathrm{~nm}$ ) of labelled protein and phospholipid components and expressed as a percentage of control labelling in the absence of added anaesthetic.

\section{Miscellaneous Analyses}

Effects of volatile anaesthetics on the accessibility of membrane sulfhydryl groups to modification by 5,5'-dithiobis-(2-nitrobenzoic acid) and on the properties of $\mathrm{Mg}^{++}$and $\mathrm{K}^{+}$stimulated membrane p-nitrophenylphosphatase were measured as outlined in our previous investigations."

\section{RESUlts}

\section{Antihaemolysis Studies}

The three inhalational agents investigated were all found to stabilize human erythrocytes against hypotonic lysis. The concentration dependence of antihaemolysis was virtually identical for halothane and methoxyflurane, including 


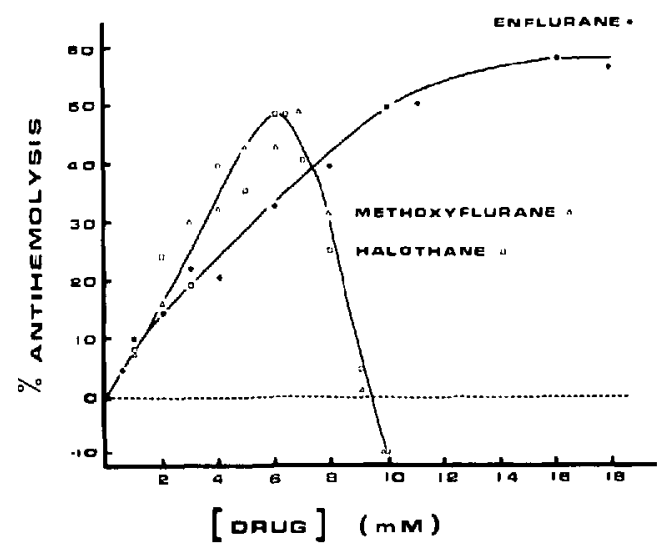

Figure 1 Effects of halothane, enflurane and methoxyflurane on the stability of human erythrocytes to hypotonic lysis. [Results are expressed as per cent antihaemolysis (i.e., the per cent decrease in control haemolysis) produced by each concentration of anaesthetic. With each drug, experiments were done in triplicate on two different blood samples.]

\section{TABLE I}

antihaemolytic Properties of Halothane, ENFluRANe and METHOXYFluRANE

$\mathrm{AH}_{8 \%}$ and $\mathrm{AH}_{50 \%}$ are concentrations of anaesthetic producing $8 \%$ and $50 \%$ antihaemolysis of human erythrocytes respectively

\begin{tabular}{lcc}
\hline \hline \multicolumn{1}{c}{ Drug } & $\mathrm{AH}_{\mathbf{8} \%}(\mathrm{mM})$ & $\mathrm{AH}_{50 \%}(\mathrm{mM})$ \\
\hline Halothane & 1.0 & 6.0 \\
Enflurane & 1.5 & 10.0 \\
Methoxyflurane & 1.0 & 6.0 \\
\hline
\end{tabular}

the typical biphasic effect of protection at low concentrations followed by destabilization at higher concentrations. In contrast, enflurane did not show any evidence of a lytic component up to the maximally attainable concentration of approximately $20 \mathrm{mM}$ (Figure 1). Anaesthetic concentrations found to produce 8 per cent antihaemolysis $\left(\mathrm{AH}_{8 \sigma_{0}}\right)$ and 50 per cent antihaemolysis $\left(\mathrm{AH}_{50 \%}\right)$, which correspond to minimum alveolar concentrations during general anaesthesia, and concentrations producing axonal conduction blockade respectively $y^{9.10}$ are summarized in Table I. The experimentally determined concentrations $\mathrm{AH}_{8 \%}$ and $\mathrm{AH}_{50 \%}$ for each anaesthetic were employed in the remainder of our studies of the membrane perturbational characteristics of these agents as described below.

\section{Chemical Labelling Studies}

The structural changes resulting from the interaction of volatile anaesthetics with the eryth- rocyte membrane were analyzed in terms of effects on the covalent labelling of membrane protein and phospholipid amino groups by trinitrophenyl moieties derived from picryl chloride (PCl). In these experiments, membranes were labelled with $\mathrm{PCl}$ in the absence or presence of anaesthetic and the extent of trinitrophenylation of membrane structural components was measured spectrophotometrically following their resolution by Sephadex G-200 gel filtration (as described in our earlier studies 11.13 using trinitrobenzenesulfonic acid as trinitrophenylating reagent). Results were expressed as per cent increase (or decrease) in protein or phospholipid labelling in the presence of anaesthetics at concentrations producing 8 and 50 per cent antihaemolysis of intact erythrocytes and our findings are summarized in Table II. At the lower concentrations of halothane and enflurane a slight decrease in phospholipid labelling was apparent, while at the higher concentrations more pronounced increases in protein labelling, unaccompanied by further increases in phospholipid labelling, were apparent with all three anaesthetics. The labelling studies were repeated using trinitrobenzenesulfonic acid (TNBS), an anionic analogue of $\mathrm{PCl}$, in order to compare the results obtained with those previously reported for propranolol" and lidocaine,,$^{13}$ two typical substances with local anaesthetic properties. All compounds were studied at their respective concentrations producing 50 per cent antihaemolysis of intact erythrocytes (i.e., $\mathrm{AH}_{50 r_{c}}$ ). The three inhalational agents all behaved rather similarly and produced equivalent increases in protein and phospholipid trinitrophenylation by TNBS (Table III). The local anaesthetics, on the other hand, caused a 3-4 fold greater incorporation into phospholipids relative to protein, although the magnitude of the stimulated incorporation into both structural components was far greater for these substances than for the inhalation anaesthetics (Table III).

The extent to which volatile anaestheticinduced membrane perturbations in erythrocytes are comparable to the situation in excitable membranes was explored using brain synaptosomal membranes and $\mathrm{PCl}$ incorporation as an index of the structural consequences of drugmembrane interaction. The results of these preliminary experiments (Figure 2) indicated a qualitative similarity between the effects of anaesthetics on the trinitrophenylation of erythrocyte and synaptosomal membrane structural components, with stimulation of protein 
TABLE II

Effects of Volatile ANaesthetics on the Trinitrophenylation of Erythrocyte Membrane Proteins and Phospholjpids by Picryl ChLORIDE

Results are expressed as mean \pm SD percentage increase in labelling produced by each agent at a concentration equal to its $\mathrm{AH}_{50}$ st value

\begin{tabular}{lccc}
\hline & & \multicolumn{2}{c}{ Increase in Labelling } \\
\cline { 3 - 4 } \multicolumn{1}{c}{ Drug } & Concentration & Protein & Phospholipid \\
\hline Halothane & $\mathrm{AH}_{\mathrm{B} \% r}$ & $-2 \pm 4$ & $-7 \pm 1$ \\
& $\mathrm{AH}_{50 \%}$ & $23 \pm 9^{*}$ & $-9 \pm 10$ \\
Enflurane & $\mathrm{AH}_{8 \%}$ & $4 \pm 4$ & $-10 \pm 3$ \\
& $\mathrm{AH}_{50 \%}$ & $30 \pm 3^{*}$ & $-3 \pm 8$ \\
Methoxyflurane & $\mathrm{AH}_{8 \%}$ & $2 \pm 6$ & $-1 \pm 10$ \\
& $\mathrm{AH}_{50 \%}$ & $36 \pm 5^{*}$ & $-1 \pm 5$ \\
\hline
\end{tabular}

* Significantly different from control labelling at $p<0.05$ level.

TABLE III

EFfects of Volatile anaesthetics and Local ANAEsthetics on the Trinitrophenylation of Erythroctte Membrane Proteins and Phospholipids By TRINITROBENZENESUlfonic ACID

Results are expressed as mean \pm SD percentage increase in labelling produced by each agent at a concentration equal to its $\mathrm{AH}_{50 \text { ric }}$ value

\begin{tabular}{lccrc}
\hline \hline & & \multicolumn{2}{c}{ Increase in Labelling } \\
\cline { 3 - 5 } \multicolumn{1}{c}{ Drug } & AH $_{\text {soc }}(\mathrm{mM})$ & Protein & Phospholipid \\
\hline Halothane & 6 & $33 \pm 1$ & $24 \pm 2$ \\
Enflurane & 10 & $18 \pm 5$ & $13 \pm 5$ \\
Methoxyflurane & 6 & $28 \pm 19$ & $23 \pm 17$ \\
Propranolol & 0.2 & $86 \pm 3$ & $380 \pm 14$ \\
Lidocaine & 10 & $167 \pm 29$ & $466 \pm 170$ \\
\hline
\end{tabular}

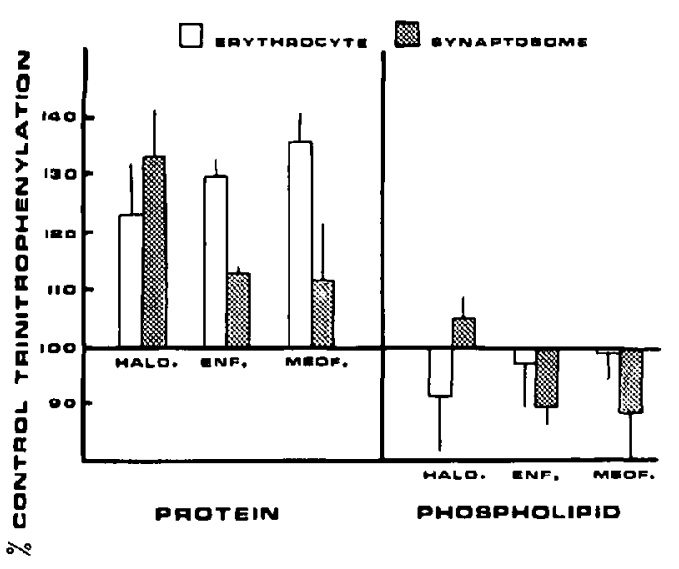

Figure 2 Effects of halothane (HALO), enflurane (ENF) and methoxyflurane (MEOF) at their respective $\mathrm{AH}_{50 \%}$ concentrations on the labelling by picryl chloride of the protein and phospholipid components of erythrocyte and synaptosomal membranes. [Results are expressed as mean \pm SD percentage incorporation relative to controls without added drug.] labelling and predominantly inhibitory effects on phospholipid labelling being observed in both systems.

We have previously shown that a variety of substances with local anaesthetic and antihaemolytic properties produce a concentrationdependent increase in the number of membrane protein sulfhydryl groups modifiable by $5,5^{\prime}$ dithiobis-(2-nitrobenzoic acid) (DTNB) and the data previously reported for propranolol ${ }^{11}$ and lidocaine ${ }^{13}$ at concentrations producing 50 per cent antihaemolysis of red cells in vitro are presented in Figure 3. While these two drugs caused a significant increase in sulfhydryl group titer, the volatile anaesthetics at concentrations associated with general anaesthesia in vivo (i.e., those required to produce 8 per cent antihaemolysis) actually caused a decrease in the accessibility and/or reactivity of membrane protein sulfhydryls (Figure 3). Similar effects were also noted at concentrations of inhalational 


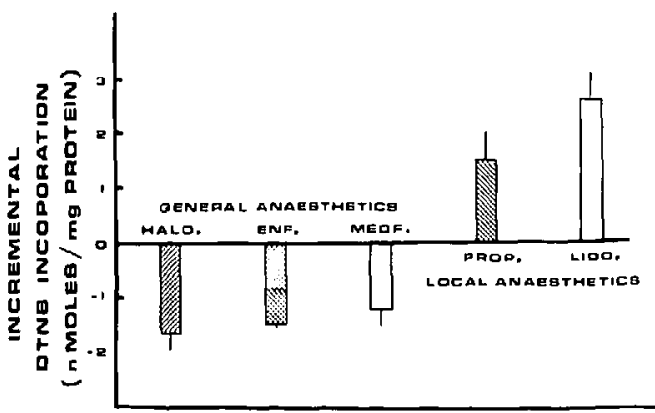

Figure 3 Effects of general anaesthetics (halothane, enflurane and methoxyflurane) at their respective $\mathrm{AH}_{\mathrm{B} / \mathrm{r}}$ concentrations and the local anaesthetics propranolol (PROP) and lidocaine (LIDO) at their $\mathrm{AH}_{50 \%}$ concentrations on the incorporation of 5,5'dithio-bis(2-nitrobenzoic acid) (DTNB) into erythrocyte membrane sulfhydryl groups. [Results are expressed as mean $\pm S D$ positive or negative incremental incorporation relative to controls without added drug.].

agents causing 50 per cent antihaemolysis of red cells (data not shown).

Another approach to studying the molecular consequences of anaesthetic-membrane interaction explored the influence of inhalational agents on the $\mathrm{Mg}^{++}$-dependent, $\mathrm{K}^{+}$-stimulated p-nitrophenylphosphatase (NPPase) system, a ouabainsensitive enzyme complex whose presence in erythrocyte and synaptosomal membranes provides another means of comparing the effects of anaesthetics on model membrane systems derived from excitable and non-excitable tissues. Arrhenius activation energies of membrane enzymes are known to be critically influenced by

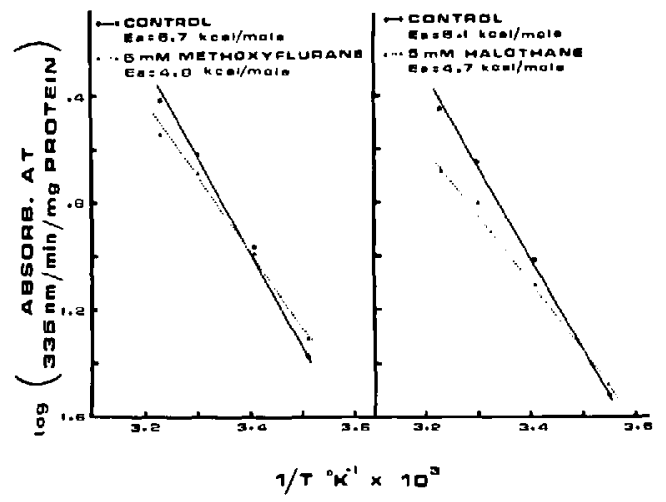

FIgURE 4 Representative Arrhenius plots of $\log$ $\left[\mathrm{K}^{+}\right.$-stimulated p-nitrophenylphosphatase activity] versus reciprocal absolute temperature for erythrocyte membranes in the absence and presence of methoxyflurane or halothane. [Activation energies were evaluated from the slope of the regression line determined using a Compucorp (Statistician) calculator.]

the physicochemical state of membrane structural components ${ }^{17.18}$ and these might, therefore, offer a sensitive and readily quantifiable index of the functional consequences of anaesthetic-membrane interaction. Effects of volatile anaesthetics on Arrhenius activation energies of basal $\left(\mathrm{Mg}^{++}\right.$.independent $), \mathrm{Mg}^{++}$. dependent, and $\mathrm{Mg}^{++}$-dependent $\mathrm{K}^{+}$-stimulated NPPase activities were examined and representative Arrhenius plots for methoxyflurane and halothane are shown in Figure 4. The data summarized in Table IV indicate highly significant effects of all three anaesthetics on the NPPase system even at concentrations $\left(\mathrm{AH}_{8 \% t}\right.$,

\section{TABLE IV}

Effects of Volatile anaesthetics on the activation Energy of Basal, $\mathrm{Mg}^{++}$. StimUlated AND $\mathrm{Mg}^{++}, \mathrm{K}^{+}$-STIMULATED p-NitrophENYLPHOSPHATASES (NPPases) OF HuMAN ERYTHROCYTE MEMBRANES

Each value represents the mean $\pm S D$ of experiments using $n$ of three different membrane preparations

\begin{tabular}{|c|c|c|c|c|}
\hline \multirow[b]{2}{*}{ Drug } & \multirow{2}{*}{$\begin{array}{c}\text { Concentration } \\
(\mathrm{mM})\end{array}$} & \multicolumn{3}{|c|}{ Activation Energy (Kcal/mole) } \\
\hline & & Basal & $\mathrm{Mg}^{++}$ & $\mathrm{Mg}^{++}+\mathrm{K}^{+}$ \\
\hline $\begin{array}{l}\text { None } \\
(n=10)\end{array}$ & - & $4.3 \pm 0.3$ & $5.7 \pm 0.4$ & $6.3 \pm 0.3$ \\
\hline $\begin{array}{l}\text { Halothane } \\
(n=3)\end{array}$ & $\begin{array}{l}1.0 \\
5.0\end{array}$ & $\begin{array}{l}3.5 \pm 0.2^{*} \\
2.6 \pm 0.2^{* *}\end{array}$ & $\begin{array}{l}4.4 \pm 0.1^{* *} \\
4.4 \pm 0.3^{* *}\end{array}$ & $\begin{array}{l}4.9 \pm 0.1^{* *} \\
5.0 \pm 0.2^{* *}\end{array}$ \\
\hline $\begin{array}{l}\text { Enflurane } \\
(\mathrm{n}=3)\end{array}$ & $\begin{array}{l}1.5 \\
7.5\end{array}$ & $\begin{array}{l}2.8 \pm 0.9^{* *} \\
3.0 \pm 0.7^{* *}\end{array}$ & $\begin{array}{l}4.7 \pm 0.4^{*} \\
4.5 \pm 0.6^{*}\end{array}$ & $\begin{array}{l}4.9 \pm 0.1^{* *} \\
5.1 \pm 0.4^{* *}\end{array}$ \\
\hline $\begin{array}{l}\text { Methoxyflurane } \\
(\mathrm{n}=3)\end{array}$ & $\begin{array}{l}1.0 \\
5.0\end{array}$ & $\begin{array}{l}2.7 \pm 0.3^{* *} \\
3.0 \pm 0.6^{* *}\end{array}$ & $\begin{array}{l}4.4 \pm 0.1^{* *} \\
4.8 \pm 0.5^{*}\end{array}$ & $\begin{array}{l}4.8 \pm 0.2^{* *} \\
4.8 \pm 0.1^{* *}\end{array}$ \\
\hline
\end{tabular}

*Significantly different from control (without drug) at $0.001<\mathrm{p}<0.01$ level.

${ }^{* *}$ Significantly different from control at $\mathrm{p}<\mathbf{0 . 0 0 1}$ level. 
TABLE V

EfFects of Volatile anaesthetics on the Activation Energy of Basal, $\mathrm{Mg}^{++}$ Stimulated and $\mathrm{Mg}^{++}, \mathrm{K}^{+}$-Stimulated NPPases of Brain Synaptosomal Membranes Control values are expressed as the mean $\pm S D$ of experiments employing four different membrane preparations, while the data on anaesthetic effects were obtained on a single synaptosomal preparation

\begin{tabular}{lcccc}
\hline \hline \multirow{2}{*}{ Drug } & $\begin{array}{c}\text { Concentration } \\
(\mathrm{mM})\end{array}$ & \multicolumn{2}{c}{ Activation Energy (Kcal/mole) } \\
\cline { 3 - 5 } & - & basal & $\mathrm{Mg}^{++}$ & $\mathrm{Mg}^{++}+\mathrm{K}^{+}$ \\
\hline None & 1.0 & $1.1 \pm 0.2$ & $3.3 \pm 0.3$ & $4.7 \pm 0.2$ \\
Halothane & 1.5 & 0.73 & 2.0 & 3.0 \\
Enflurane & 1.0 & 0.66 & 2.4 & 3.0 \\
Methoxyflurane & & 0.41 & 2.7 & 3.2 \\
\hline
\end{tabular}

corresponding to minimum alveolar concentrations during anaesthesia) which did not detectably alter the incorporation of picryl chloride into erythrocyte membrane structural components (Table II). Preliminary experiments indicate that comparable membrane perturbational actions of volatile anaesthetics at clinically relevant concentrations are also observed in the NPPase system of brain synaptosomal membranes (Table V).

\section{Discussion}

Although much detailed information exists concerning the ability of anaesthetics to interact with and perturb natural membranes or proteinfree artificial lipid bilayer systems, little is known about the molecular basis of anaesthesia, whether at the level of the single neurone or of the intact animal. Model experiments using isolated in vitro preparations are frequently hampered by uncertainties regarding the use of anaesthetic concentrations greatly in excess of those encountered clinically and also by the lack of information concerning the relative involvement of protein and lipid structural components in anaesthetic-induced membrane functional alterations. In the light of these limitations, the human erythrocyte provides a convenient model membrane system for studying anaesthetics, since concentrations producing 8 and 50 per cent antihaemolysis correlate well with concentrations required for the production of general and local anaesthesia, respectively; $;^{10}$ and the membrane perturbational properties of various agents may be analyzed, at concentrations producing an equivalent degree of erythroycte stabilization, in terms of their effects on the incorporation of group-specific chemical probes into membrane proteins and phospholipids. ${ }^{11,13}$

Although local and general anaesthetics undoubtedly differ in their sites of pharmacological action in vivo, both groups of agents ultimately act to stabilize membrane potential and prevent the increase in sodium conductance governing the rising phase of the action potential. It has, therefore, been suggested that local and general anaesthetics may share a common molecular mode of action at the membrane level.9.10.19 Consistent with this possibility is the demonstration that elevated ambient pressures (of the order of 100 atmospheres) are able effectively to antagonize the effects of both classes of agents on the neuronal compound action potential. ${ }^{20}$ Further, spin label experiments have shown that halothane and lidocaine exert comparable biphasic effects on the fluidity of synaptic membranes, with increased ordering being apparent at low concentrations of anaesthetic and overall fluidization predominating at higher concentrations. ${ }^{21}$ On the other hand, it has been shown that the blockade of frog sciatic nerve preparations by halothane is enhanced by increasing calcium concentration or replacement of $\mathrm{H}_{2} \mathrm{O}$ by $\mathrm{D}_{2} \mathrm{O}$, while blockade by procaine is antagonized by calcium and unaffected by $\mathrm{D}_{2} \mathrm{O} .^{22}$ These latter observations are in accord with the results of the present investigation and suggest that the membrane perturbational characteristics of local and general anaesthetics are not equivalent.

The interaction of inhalational anaesthetics with human erythrocyte membranes at concentrations of anaesthetic producing 50 per cent antihaemolysis of erythrocytes in vitro $\left(\mathrm{AH}_{50 \%}\right)$ caused an increase in the incorporation of picryl chloride $(\mathrm{PCl})$ into membrane protein compo- 
nents with marginal effects on membrane phospholipid labelling (Table II). The non-polar characteristics, both of the $\mathrm{PCl}$ molecule and of the anaesthetics, suggest that the protein perturbations in question may be occurring in the internal hydrophobic core of the membrane, possibly as the result of direct anaestheticprotein interactions. Parallel experiments using trinitrobenzenesulfonic acid (TNBS), a highlycharged analogue of $\mathrm{PCl}$, indicate that more superficially located membrane sites are also modified in the presence of anaesthetics, but in a less selective manner, with equivalent changes in protein and phospholipid moieties (Table III). Two substances with local anaesthetic activity, namely propranolol and lidocaine, when examined under the same conditions (i.e., at their respective $\mathrm{AH}_{50 \%}$ values and, hence, at equivalent concentration in the membrane), exhibited considerably greater increases in protein and particularly phospholipid labelling by TNBS (Table III). The constant ratio of phospholipid to protein, which characterizes the increased TNBS labelling in the presence of general anaesthetics, suggests that these molecules share common membrane perturbational actions. In contrast, substances possessing local anaesthetic properties exhibit considerable differences in their relative abilities to influence TNBS incorporation into protein or phospholipid components of membranes (Table III).

Further evidence for the distinction between the membrane actions of local and general anaesthetics was obtained in experiments using $5,5^{\prime}$ dithio-bis-(2-nitrobenzoic acid) (DTNB) to detect changes in the configurational state of membrane protein sulfhydryl groups. The work of Borochov et al. ${ }^{23}$ has shown that alterations in erythrocyte membrane fluidity (resulting from experimentally-induced elevation of the cholesterol to phospholipid ratio) are associated with changes in the susceptibility of membrane sulfhydryls to chemical modification. Earlier studies from our own laboratory (see results with propranolol and lidocaine in Figure 3 and Reference 13) had also shown that local anaesthetics cause a progressive increase in the modification of erythrocyte membrane sulfhydryls by DTNB. Since local and general anaesthetics are both known to induce fluidization of membrane lipids, ${ }^{1}$ the finding that all three inhalational agents at surgical concentrations $\left(\mathrm{AH}_{8} \%\right.$, Figure 3$)$ or greater (AH $\mathrm{A}_{50 \%}$, data not shown) produced a decrease in DTNB-accessible sulfhydryl groups was some- what unexpected. While these results might indicate that the nature and consequences of membrane fluidization induced by general and local anaesthetics are quite different, a more likely explanation is that the observed effects may result from direct interaction of anaesthetics with membrane proteins. The influence of the volatile anaesthetics on the activation energies of erythrocyte membrane p-nitrophenylphosphatase (NPPase) activities (Figure 4) provided further evidence for the involvement of membrane proteins in the membrane perturbational actions of general anaesthetics at clinically relevant concentrations (Table IV). Anaesthetics also produced a modest, but consistent, decrease in enzyme activity which became more pronounced with increasing temperature (see Figure 4). A similar temperature-dependence has recently been noted for the inhibition by halothane of calcium transport activity in skeletal muscle fragmented sarcoplasmic reticulum. ${ }^{24}$ Since the antihaemolytic properties of inhalational anaesthetics were essentially independent of temperature in the range of $5^{\circ}$ to $37^{\circ} \mathrm{C}$ (data not shown), it seems likely that an effect of temperature on the configurational state of the membrane proteins in question rather than on anaesthetic-membrane interaction per se is involved. Our preliminary experiments using brain synaptosomal membranes as a model excitable membrane system indicate that the structural (Figure 2) and functional (Table V) consequences of general anaesthetic-membrane interaction in this preparation are qualitatively quite similar to the situation in erythrocytes (Figure 2, Table IV).

We have shown, therefore, that inhalational general anaesthetics differ markedly from local anaesthetics in their erythrocyte membrane perturbational characteristics when both are compared at concentrations producing equivalent stabilization of human erythrocytes against hypotonic lysis (i.e., $\mathrm{AH}_{50 \%}$ ). Under these conditions, local anaesthetics exert a major effect on the configurational state of membrane phospholipids, with a lesser action on membrane proteins while general anaesthetics perturb both these membrane structural components to a much lesser degree and both to approximately the same extent. At lower concentrations, however, general anaesthetics appear preferentially to alter membrane protein components. Much recent speculation has focussed on the possible role of proteins in mediating the membrane actions of general anaesthetics, based largely on the obser- 
vation that natural membranes are more susceptible to the modifying influence of anaesthetics than artificial bilayer systems. ${ }^{7,25-27}$ Our observations at clinically relevant concentrations of general anaesthetics (i.e., $\mathrm{AH}_{\mathbf{8} \%}$ ) offer support for this hypothesis and underline the striking differences in the molecular characteristics of general and local anaesthetic action at the membrane level. These differences, which are revealed at concentrations required to produce their respective pharmacological effects, suggest that a diversity exists in the molecular basis of anaesthesia produced by these two classes of pharmacological agent.

\section{ACKNOWLEDGEMENTS}

We wish to express our thanks to Mrs. Therese $\mathrm{Ng}$ for her expert technical assistance throughout the course of this study and gratefully acknowledge the financial support of the Medical Research Council of Canada.

\section{REFERENCES}

1. KaUfMAN, R.D. Biophysical mechanisms of anesthetic action: historical perspectives and review of current concepts. Anesthesiology 46: 49-62 (1977).

2. Halsey, M.J., WARDley-Smith, B. \& Green, C.J. Pressure reversal of general anesthesia - a multi-site expansion hypothesis. Brit. J. of Anaesthesia 50: 1091-1097 (1978).

3. Richards, C.D. \& Hesketh, T.R. Implications for theories of anaesthesia of antagonism between anaesthetic and non-anaesthetic steroids. Nature 256: 179-182 (1975).

4. Arndt, J.O. \& Freye, E. Opiate antagonist reverses the cardiovascular effects of inhalational anaesthesia. Nature 277: 399-400 (1979).

5. Lenaz, G., Curatola, G., Mazzanti, L. \& Parenti-Castelli, G. Biophysical studies on agents affecting the state of membrane lipids: biochemical and pharmacological implications. Molecular and Cellular Biochemistry 22: 3-32 (1978).

6. Mastrangelo, C.J., Trudell, J. R., Edmunds, H.N. \& COHEN, E.N. Effects of clinical concentrations of halothane on phospholipid-cholesterol membrane fluidity. Molecular Pharmacology 14: 463-467 (1978).

7. Lenaz, G., Curatola, G., Mazzanti, L., Parenti-Castelli, G. \& Bertoli, E. Effects of general anesthetics on lipid protein interactions and ATPase activity in mitochondria. Biochemical Pharmacology 27: 2835-2844 (1978).

8. Ueda, I. \& Kamaya, H. Kinetic and thermodynamic aspects of the mechanism of general anesthesia in a model system of firefly luminescence in vitro. Anesthesiology 38: 425-436 (1973).

9. Seeman, P. Membrane actions of anesthetics and tranquilizers. Pharmacological Reviews 24: 583655 (1972).
10. Roth, S. \& Seeman, P. All lipid-soluble anaesthetics protect red cells. Nature (New Biology) 23/: 284-285 (1971).

11. Godin, D.V., NG, T. WAN \& Tuchek, J.M Studies on the interaction of propranolol with erythrocyte membranes. Biochim. Biophys. Acta 436: 757-773 (1976).

12. Godin, D.V., Au, T. \& Garnett, M.E. Acetyl. cholinesterase: a probe for the study of antiarrhythmic drug-membrane interactions. Biochim. Biophys. Acta 512: 388-396 (1978).

13. Godin, D.V., Au, T. \& Garnett, M.E. Membrane perturbational effects of antiarrhythmic drugs. J. Molec. Cell. Cardiol. 1I: 261-274 (1979).

14. Godin, D.V. \& Schrier, S.L. Mechanism of inactivation of erythrocyte membrane adenosine triphosphatase by carbodiimides. Biochemistry 9: 4068-4077 (1970).

15. Jones, D.H. \& Matus, A.I. Isolation of synaptic plasma membrane from brain by combined flotation-sedimentation density gradient centrifugation. Biochim. Biophys. Acta 356: 276-287 (1974).

16. Cooperstein, S.J. \& Lazarow, A microspectrophotometric method for the determination of cytochrome oxidase. J. Biol. Chem. 189: 665-670 (1951).

17. Kimelberg, H.K. Alterations in phospholipiddependent $\left(\mathrm{Na}^{+}+\mathrm{K}^{+}\right)$-ATPase activity due to lipid fluidity. Effects of cholesterol and $\mathrm{Mg}^{2+}$. Biochim. Biophys. Acta 413: 143-156 (1975).

18. McMurchie, E.J.\& Raison, J.K. Membrane lipid fluidity and its effect on the activation energy of membrane-associated enzymes. Biochim. Bicphys. Acta 554: 364-374 (1979).

19. Frank, G.B. Drugs which modify membrane excitability. Fed. Proc. 27: 132-136 (1968).

20. Kendig, J.J. \& CoHEN, E.N. Pressure antagonisrn to nerve conduction block by anesthetic agents. Anesthesiol. 47: 6-10 (1977).

21. Rosenberg, P.H. Effects of halothane, lidocaine and 5-hydroxytryptamine on fluidity of synaptic plasma membranes, myelin membranes and synaptic mitochondrial membranes. Naunyn-Schmiedeberg's Arch. Pharmacol. 307: 199-206 (1979).

22. Diamond, B.I., Havdala, H.S. \& Sabelli, H.C. Differential membrane effects of general and local anesthetics. Anethesiol. 43:651-660 (1975).

23. Borochov, H., Abbott, R.E., Schochter, D. \& ShINITZKY, M. Modulation of erythrocyte membrane proteins by membrane cholesterol and lipid fluidity. Biochem. 18: 251-255 (1979).

24. Diamond, E.M. \& Berman, M.C. The effect of halothane on the stability of $\mathrm{Ca}^{2+}$ transport activity of isolated fragmented sarcoplasmic reticulum. Biochem. Pharmacol. 29: 375-381 (1980).

25. Lenaz, G., Curatola, G., Mazzanti, L., BerToli, E. \& PostreszKo, A. Spin label studies on the effects of anesthetics in synaptic membranes. J. Neurochem. 32: 1689-1695 (1979).

26. Franks, N.L.P. \& Lieb, W.R. Where do general anesthetics act? Nature 274: 339-342 (1978).

27. SEEMAN, P.The membrane expansion theory of anesthesia: direct evidence using ethanol and a high precision density meter. Experientia 30: 759-760 (1974). 


\section{RÉSUMÉ}

L'interaction de trois anesthésiques volatils (halothane, enflurane et méthoxyflurane) avec la membrane érythrocytaire utilisés à des concentrations qui protègent les érythrocytes intacts contre la lyse hypotonique a été étudiée avec l'espoir d'obtenir des renseignements fondamentaux sur les perturbations caractéristiques que causent ces substances lorsqu'on les compare aux anesthésiques locaux. Les agents anesthésiques volatils ont augmenté la susceptibilité des protéines de la membrane et, à un degré moindre, des phospholipides à la trinitrophénylation par le chlorure de picryl ou l'acide trinitrobenzènesulfonique mais a diminué l'accessibilité des groupes protéiques sulfhydryl de la membrane à la modification apportée par l'acide 5,5'-dithio-bis-(2-nitrebonzoïque). Ces observations contrastaient fortement avec nos données précédentes concernant les anesthésiques locaux par le fait que lorsque ces substances étaient comparées aux anesthésiques généraux à des concentrations qui produisaient une stabilisation êrythrocytaire équivalente, elles causaient une augmentation plus marquée de la trinitrophénylation, intéressant plus spécialement le composé phospholipidique et une augmentation de l'exposition du groupe sulfhydryl de la membrane. Une évidence additionnelle démontrant les altérations des protéines de la membrane produites par des concentrations d'anesthésiques volatils identiques à celles que l'on emploie en anesthésie chirurgicale fut obtenue lorsqu'on a observé que les trois agents produisaient une baisse significative de l'activation de l'énergie des p-nitrophénylphosphatases liées à la membrane. Une étude préliminaire faite avec des membranes post-synaptiques du cerveau porte à croire que les conséquences structurelles et fonctionnelles de l'interaction anesthésique sur la membrane érythrocytaire peuvent être identiques à celles qui surviennent dans les tissus excitables. Nos données indiquent done que les agents anesthésiques locaux et généraux causent des altérations distinctes sur les propriétés des membranes et que ceci peut se réfléter par des différences correspondantes sur les mécanismes moléculaires d'action des différents groupes d'agents anesthésiques. 